\title{
The unit trust industry in South Africa from 1965 to June 2005: are investors better off?
}

\author{
MC Meyer-Pretorius
}

HP Wolmarans

Department of

Financial Management

Department of University of Pretoria

\author{
Financial Management \\ University of Pretoria
}

\begin{abstract}
The vast global unit trust/mutual fund industry was worth more than $\$ 16$ trillion by the end of June 2005. Over time, investors' interests seem to have shifted from individual shares to share funds. The unit trust industry in South Africa is no exception. Over the 40-year period from its inception in 1965 to 2005, the industry has grown from only one fund to 567 different funds, worth more than R345 billion.

This study highlights some of the most important changes that have occurred in the South African unit trust industry over the last 40 years. These shifts are compared to changes that the USA mutual fund industry has experienced in the 60 years of its existence. An attempt is then made to answer the question whether South African investors are better off with these changes or not.
\end{abstract}

Key words

Collective investments

Equity funds

Money market funds

Mutual funds

Specialised funds

Units trust industry

\section{Introduction}

Across the world, the unit trust/mutual funds industry has become a vast industry. By the end of June 2005, it was worth \$16.41 trillion and managing 55920 different funds in 41 countries (ICI 2005). From a small industry, offering a relatively small number of funds, mostly diversified equity and balanced funds, it has changed into a multi-trillion-dollar industry offering thousands of funds with diverse investment policies and strategies.

The unit trust industry in South Africa started as a single fund in June 1965. This fund was established to offer the ordinary investors a convenient investment product which allowed assets to be managed professionally, spread risk across a broad portfolio of shares, provided the investor with the ability to liquidate the investment at short notice, required

Meditari Accountancy Research Vol. 14 No. $12006: 49-67$ 49 
low initial investment amounts, and ensured tax effectiveness and low cost, compared to other products available at the time (Oldert 2005:30).

By June 2005, there were 567 unit trusts, with total assets valued at more than R345 billion. In contrast to single equity funds, the unit trust industry has grown to include money market funds, gilt funds, many specialist equity funds, international funds, funds of funds, wrap funds and index funds. The two main factors that led to this explosion of funds were increased consumer sophistication with regard to what consumers demand from different investment products on the one hand, and inevitable product differentiation on the part of management companies on the other (Oldert 2005:33). By December 2005, there were 617 funds worth R415 billion, and South African unit trust assets breached the R400 billion mark for the first time (ACI 2006b). These figures indicate that unit trusts have become a popular savings channel for the more than two million South Africans who currently invest in unit trusts.

Out of 41 countries, South Africa now ranks $22^{\text {nd }}$ in terms of the dollar value of the assets under management (ICI 2005). The South African industry was worth $\$ 52.3$ million in June 2005 , constituting $0.3 \%$ of assets managed by unit trusts worldwide. South Africa is ahead of countries such as New Zealand, Russia, Portugal, Mexico and Norway.

\section{The aim of the study}

This study reports on a number of developments that took place worldwide and also in South Africa over the past forty years, namely:

an increase in the number of funds;

an increase in different types of funds;

differentiation between general equity and other equity funds;

changes in management style;

changes in the ownership of unit trusts/changes in the shareholding of JSE equities;

changes in the investment strategies of portfolio managers;

changes in the length of investment by investors;

increases in the creation of new funds and the closing down/merging of existing funds; and

changes in the cost structure of unit trusts.

In this study, a comparison is drawn between developments in the South African unit trust industry and that of the USA mutual fund industry. The term 'mutual fund' refers to openended investment companies with redeemable shares in the USA, similar to unit trusts in South Africa. The difference between mutual funds and unit trusts lies in their structure the end result for the investor is much the same. A unit trust is overseen by a trust company, while in a mutual fund it is the responsibility of the directors of the mutual fund company to ensure that the fund manager and the custodian perform their duties in accordance with the constituent documents (Oldert 2005:30). The USA mutual fund industry represents 50\% of mutual fund assets worldwide. In this study, the impact of these developments is evaluated and an attempt is made to answer the question of whether the South African investor is better off with these changes or not. 


\section{Literature review}

Most of the recent research on unit trusts has focused on the performance of these trusts. Examples of such studies are those by Collinet and Firer (2003:523), Pinnuck (2003:811), Akinjolire and Smit (2003:41), Kjetsaa (2004:102), Fletcher and Marshall (2005:183), Noulas, Papanastasiou and Lazaridis (2005:101) and Lin (2006:147). Without exception these researchers agree that, although the performance of individual trusts may differ, as an investment vehicle, unit trusts offer a small investor an acceptable, inflation-beating return over the medium to long term, while the excitement of the upside potential of the stock market makes this type of investment attractive.

Investors have successfully used unit trusts/mutual funds to supplement retirement funds. Krell (2005:27) remarks that an increasing number of investors worldwide are investing in unit trusts in order to provide for retirement, as the performance of companies' retirement funds often fall short of expectations. Rusconi (2005:16) has found evidence of the same pattern in South Africa, as well as that unit trusts are, on average, more cost-effective in providing for retirement funding than individual life insurance products.

Some studies, such as that by Ellingham (1995:28) cover property unit trusts, but most of the research pertains to aspects relevant to a unit trust investor focused on funds investing in equities. Gronewoller, McLeod and Rose (2001:1) remark that style analysis may be useful when evaluating the risk-adjusted performance of unit trusts. Fletcher, Forbes and Marshall (2002:173) investigated the impact of the use of derivatives on the risk and performance of unit trusts. Gaber, Gregoriou and Kelting (2004:328) studied the performance of funds of hedge funds. Barber, Odean and Zheng (2005:2117) analysed mutual fund flows over a period of 30 years and found that, although investors seem to be sensitive to front-end-load fees like commissions, they are much less sensitive to recurring costs like operating expenses. Hayes (2005:59) considered some of the issues involved when investors choose funds that invest in a socially responsible way, while Tessitore and Usmen (2005:150) studied the performance of funds-of-funds.

In South Africa, unit trust research has also focused mainly on performance. Collinet and Firer (2003:523) have investigated the persistence of the performance of general equity funds, as did Wessels and Krige (2005:71). After analysing the performance of twenty top unit trusts for the period from 1998 to 2002, Oldham and Kroeger (2005:81) concluded that unit trust fund managers were unable to generate consistent above-average returns for their investors over this period.

Only a few studies were performed to provide an overview of the unit trust industry in a specific country. Examples of these include surveys in Singapore (Kee 1999:49), Malaysia (Ramasamy \& Yeung 2003:122), Canada (Deaves 2004:326) and the USA (Bogle 2005:15). A need for a similar survey of the South African unit trust industry was identified, and this study attempts to meet that need.

\section{The unit trust industry in South Africa from June 1965 to June 2005}

From a modest beginning in June 1965 with one fund (Sage) and an asset value of R600 000, the unit trust industry has grown to 567 different funds, which already controlled assets of more than R415 billion by December 2005. In Table 1 the average growth per

Meditari Accountancy Research Vol. 14 No. 12006 : 49-67 
five-year period for both the South African GDP and the value of assets of South African unit trusts are given.

Table 1 Monetary growth in economy (GDP) and growth in unit trusts assets from 1965 to 2005

\begin{tabular}{|l|r|c|c|c|}
\hline Year & \multicolumn{1}{|c|}{$\begin{array}{c}\text { GDP } \\
\mathbf{( R m})\end{array}$} & $\begin{array}{c}\text { Annual compounded } \\
\text { growth rate }\end{array}$ & $\begin{array}{c}\text { Unit trusts } \\
\mathbf{( R m})\end{array}$ & $\begin{array}{c}\text { Annual compounded } \\
\text { growth rate }\end{array}$ \\
\hline 1965 & 7197 & & 0.6 & \\
\hline 1970 & 12791 & $12.19 \%$ & 358 & $259.04 \%$ \\
\hline 1975 & 27323 & $16.39 \%$ & 313 & $-2.65 \%$ \\
\hline 1980 & 62730 & $18.08 \%$ & 695 & $17.30 \%$ \\
\hline 1985 & 127598 & $15.26 \%$ & 1540 & $17.25 \%$ \\
\hline 1990 & 289816 & $17.83 \%$ & 7550 & $37.43 \%$ \\
\hline 1995 & 548100 & $13.59 \%$ & 33695 & $34.87 \%$ \\
\hline 2000 & 922148 & $10.97 \%$ & 128385 & $30.67 \%$ \\
\hline 2005 & 1529658 & $10.65 \%$ & 415131 & $26.45 \%$ \\
\hline AVG (1965-2005) & & $14.34 \%$ & & $39.55 \% \%$ \\
\hline AVG (1970-2005) & & $14.65 \%$ & & $22.34 \%$ \\
\hline
\end{tabular}

Sources: The SA Reserve Bank (2005) and ACl (2006). The values for unit trusts and GDP in 1965 were June values. For all other years, December values were used.

The strong growth in the South African unit trust industry from its inception to 1970 is clear from Table 1. This period includes the crash of May 1969. The industry grew at an average rate of $259 \%$ per annum. The growth in the industry was very slow during the 1970s and it took the industry about ten years to recover to levels it had reached prior to the crash of May 1969. The unit trust industry's growth rate increased again during the second half of the 1980s when the average annual growth increased from around $17 \%$ to around $37 \%$, until the minor crash in 1987. However, compared to the crash of 1969 , the 1987 fall in JSE prices had a minimal effect on the long-term growth of the industry. The large demand for unit trusts as an investment vehicle is, moreover, illustrated by the compound annual growth rate of nearly $40 \%$ per annum over the past 40 years in relation to the growth of the total economy of only $14 \%$. If one omits the outliers and calculate the average compounded growth rate for the period from 1970 to 2005 , the rate is $22.34 \%$, which is still about $8 \%$ higher than the growth of the general economy.

The USA mutual fund industry started in 1945 and it is therefore twenty years older than the South African industry. The USA industry had a compound annual growth rate of $16 \%$, while the total economy grew by only $7 \%$ in monetary terms over the same period (Bogle 2005:15). By comparison, the South African unit trust industry grew by a compound annual rate of $39 \%$, while the economy grew by only $14 \%$. These figures for the two countries are, however, not strictly comparable, because the time spans (40 and 60 years respectively) differ. The rates of inflation also differ between the two countries. Results in both countries, however, indicate that the unit trust/mutual funds industry has grown at an exceptionally rapid rate in relation to their economies and highlights the strong demand for these investment products. 


\subsection{Increases in the number of funds}

In most respects, the South African unit trust industry follows the same pattern as that of the US unit trust market. International occurrences are reflected in South Africa, but on a smaller scale. In the USA, mutual funds increased from 68 funds in 1945 to 8200 funds by the end of 2005. In South Africa, over the 40-year period, funds grew from one fund in 1965 to 617 different funds in December 2005. Table 2 illustrates the growth in the number of funds over the 40-year period. Only selected years are listed, as between 1965 and 1980 the number of funds, for instance, did not increase by nearly as much as between 1995 and 2000 .

Table 2 Growth in the number and value of funds

\begin{tabular}{|l|c|c|c|}
\hline Date & Number of funds & $\begin{array}{c}\text { Asset value } \\
\text { (Millions of rand) }\end{array}$ & $\begin{array}{c}\text { Compounded annual } \\
\text { growth in asset value }\end{array}$ \\
\hline Dec 1965 & 2 & $\mathrm{R} 3.00$ & \\
\hline Dec 1980 & 12 & $\mathrm{R} 682.80$ & $43.60 \%$ \\
\hline Dec 1990 & 36 & $\mathrm{R} 7550.10$ & $27.17 \%$ \\
\hline Dec 1995 & 88 & $\mathrm{R} 33675.00$ & $34.86 \%$ \\
\hline Dec 2000 & 334 & $\mathrm{R} 128384.70$ & $30.69 \%$ \\
\hline Dec 2005 & 617 & $\mathrm{R} 415131.00$ & $26.46 \%$ \\
\hline
\end{tabular}

Sources: Lambrechts (1995), Lambrechts (2000), ACI (2006).

Sage launched the first unit trust on 14 June 1965, with initial assets worth about R600 000 . By the end of 1965, there were two funds with an asset value of R3 million. In the following 15-year period from 1965 to 1980, only ten new funds were launched. The average growth per annum for that period was high, because of the low base and the initial high growth rate until the crash of 1969 . The unit trust industry experienced strong growth during the second half of the 1980s, namely in 1987 when 11 new funds were established in a single year. By December 1990, the industry had grown to 36 different funds, worth R7.5 billion. The comparatively rapid growth in the number of funds in the $1980 \mathrm{~s}$ is, however, insignificant compared to the number of funds added in the 1990s and since the start of 2000. In December 2000, there were already 334 different funds, with an asset value of R128.4 billion. By June 2005, there were 567 different funds with an asset value of R345.9 billion. This then increased to 617 funds worth more than R415 billion by December 2005.

The growth in the number of funds and the growth in assets values in the USA and in South Africa highlights the importance of unit trusts/mutual funds as an investment product. It should be stressed that the compound annual growth rate of about $30 \%$ in South African unit trust assets over the last decade is not so much a function of the high performance of the unit trust portfolio managers, but rather of the popularity of this inflation-beating investment vehicle among investors.

\subsection{Increase in different types of funds}

The types of securities in which South African unit trusts invest have changed over time. Equity fund assets still represent the bulk of all worldwide mutual fund assets (International Investment Fund Association, as published by ICI 2005). By June 2005, equity funds represented $43 \%$, money market funds $19 \%$, and bond funds $20 \%$ of worldwide assets 
under management. Balance/mixed funds represented $9 \%$ and other/unclassified funds represented another $9 \%$.

In South Africa, the bulk of investment (49\% of asset values) and $77 \%$ of the funds (437 of the 567 funds at June 2005) are still invested in equities. In Table 3 the distribution of value of assets between equity and other types of South African funds for selected years is given.

Table 3 Distribution of the value between equity and other funds

\begin{tabular}{|c|c|c|c|c|c|c|c|c|}
\hline \multirow[b]{2}{*}{ Type } & \multicolumn{2}{|c|}{1990} & \multicolumn{2}{|c|}{1995} & \multicolumn{2}{|c|}{2000} & \multicolumn{2}{|c|}{ June 2005} \\
\hline & $\begin{array}{l}\text { No of } \\
\text { funds }\end{array}$ & $\begin{array}{c}\text { Assets } \\
\text { (R bn) }\end{array}$ & $\begin{array}{l}\text { No of } \\
\text { funds }\end{array}$ & $\begin{array}{l}\text { Assets } \\
\text { (R bn) }\end{array}$ & $\begin{array}{l}\text { No of } \\
\text { funds }\end{array}$ & $\begin{array}{c}\text { Assets } \\
\text { (R bn) }\end{array}$ & $\begin{array}{l}\text { No of } \\
\text { funds }\end{array}$ & $\begin{array}{l}\text { Assets } \\
\text { (R bn) }\end{array}$ \\
\hline Equity & 28 & $\begin{array}{l}7.136 \\
(94 \%) \\
\end{array}$ & 65 & $\begin{array}{r}30.121 \\
(89 \%) \\
\end{array}$ & 273 & $\begin{array}{r}75.012 \\
(59 \%) \\
\end{array}$ & 437 & $\begin{array}{r}167.697 \\
(49 \%)\end{array}$ \\
\hline Bond & 8 & $\begin{array}{r}0.437 \\
(6 \%) \\
\end{array}$ & 23 & $\begin{array}{l}3.549 \\
(11 \%) \\
\end{array}$ & 42 & $\begin{array}{r}20.053 \\
(16 \%) \\
\end{array}$ & 104 & $\begin{array}{r}62.919 \\
(18) \% \\
\end{array}$ \\
\hline $\begin{array}{l}\text { Money } \\
\text { Market }\end{array}$ & - & & - & & 19 & $\begin{array}{r}31.856 \\
(25 \%)\end{array}$ & 26 & $\begin{array}{r}115.304 \\
(33 \%)\end{array}$ \\
\hline Total & 36 & 7.573 & 88 & 33.670 & 334 & 126.921 & 567 & 345.920 \\
\hline
\end{tabular}

Sources: Lambrechts (1990, 1995, 2000 and 2005).

Of the 12 South African funds available at the end of 1980, all but one was an equity fund. The first non-equity fund, a fixed interest fund, namely Standard Bank Extra Income fund, was launched in 1978. By June 2005 bonds (fixed interest funds) represented $18 \%$ of the market. The attractiveness of fixed income funds in South Africa is in line with international trends, for instance, in the USA, where bond funds represent $17 \%$ of the market. The worldwide figure is $20 \%$.

After many years of resistance from the banking sector, which had a monopoly on the investment of short-term funds, South African money market unit trusts were introduced in 1997. By December 2000, there were 19 money market funds, representing $25 \%$ of the total market value of assets. By June 2005, the number of money market funds increased to 26 , representing $33 \%$ of the total assets of the industry. In the USA, money market funds already constituted $26 \%$ of the total market, while the worldwide figure was $19 \%$. The higher representation of money market funds in South Africa is a possible indication that South African investors are still more risk-averse than their international counterparts.

\subsection{Differentiation between general equity and other equity funds}

As indicated previously, equity funds still dominated the market (49\% of asset value) in June 2005. However, whereas general equity funds were quite popular in the 1970s, they now only represent about $32 \%$ of the equity fund market and $16 \%$ of the total unit trust market, as indicated in Table 4 (for selected years). 
Table 4 Differentiation in equity funds

\begin{tabular}{|l|c|c|c|c|c|c|}
\hline \multirow{2}{*}{ Type of funds } & \multicolumn{2}{|c|}{1990} & \multicolumn{2}{c|}{1995} & \multicolumn{2}{c|}{ 2005 June } \\
\cline { 2 - 7 } & $\begin{array}{c}\text { No of } \\
\text { funds }\end{array}$ & $\begin{array}{c}\text { Assets } \\
\text { (R bn) }\end{array}$ & $\begin{array}{c}\text { No of } \\
\text { funds }\end{array}$ & $\begin{array}{c}\text { Assets } \\
\text { (R bn) }\end{array}$ & $\begin{array}{c}\text { No of } \\
\text { funds }\end{array}$ & $\begin{array}{c}\text { Assets } \\
\text { (R bn) }\end{array}$ \\
\hline General equity & 16 & $\begin{array}{c}5.996 \\
(84 \%)\end{array}$ & 24 & $\begin{array}{r}23.918 \\
(80 \%)\end{array}$ & 73 & $\begin{array}{c}54.297 \\
(32 \%)\end{array}$ \\
\hline Specialized funds & 12 & $\begin{array}{c}1.140 \\
(16 \%)\end{array}$ & 25 & $\begin{array}{c}3.950 \\
(13 \%)\end{array}$ & 79 & $\begin{array}{c}38.550 \\
(23 \%)\end{array}$ \\
\hline Balanced/managed & & & 10 & $\begin{array}{c}1.852 \\
(6 \%)\end{array}$ & 199 & $\begin{array}{c}56.850 \\
(34 \%)\end{array}$ \\
(asset allocation) & & & 6 & 0.400 & 86 & $\begin{array}{c}18.002 \\
(11 \%)\end{array}$ \\
\hline International & & & 65 & 30.120 & 437 & 167.699 \\
\hline Total & 28 & 7.136 & & & & \\
\hline
\end{tabular}

Sources: Lambrechts (1990, 1995 and June 2005).

Regardless of fund manager skills, broad-based equity funds tend to rise and fall with the JSE Securities Exchange (JSE) overall index. In the late 1980s and early 1990s, fund managers of general equity funds found performance constrained by the unpredictable performance of mining stocks (which made up a significant portion of the value of the JSE). To achieve proper diversification, however, fund managers could not leave mining stocks out of their portfolios. The unpredictable performance of mining stock led to the establishment of funds that focused exclusively on financial or industrial shares.

Today there are nine categories of these specialised funds, representing $23 \%$ of the equity market. Lambrechts (2005) classifies these funds as follows:

growth funds;

large capitalisation funds;

value funds;

smaller companies funds;

varied specialist funds;

resources and basic industries funds;

industrial sector funds;

financial and industrial sector funds; and

financial sector funds.

Two other categories of equity fund have been established, namely:

international funds; and

balanced/managed funds.

Until the end of the 1980s, international diversification in South Africa was restricted. The deregulation of foreign investment during 1995 had a significant impact on the South African unit trust industry and wide ranges of products became available. By June 2005, international funds represented $11 \%$ of the equity market, and 86 different funds were available to investors.

An important development in unit trusts centred on managed funds, which allowed unit trusts to attract investments that had historically been preserved for the retirement funding industry. By June 2005 this category represented 34\% of the equity market, with 199 different funds. 
These diversification trends occur among equity funds worldwide. In the USA, general equity represented only $14 \%$ in 2005 , other diversified equity funds $59 \%$, specialised funds $11 \%$ and international funds $16 \%$ of the total number of equity funds. Choosing a fund today requires the same skills as selecting an individual share did in the past. Hence, many investors nowadays hold portfolios of funds rather than portfolios of shares.

\subsection{Changes in management style}

Most of the older management companies initially sold only life insurance products (for example, Old Mutual, Sanlam and Liberty) or were banks (RMB, Absa and Standard Bank). More recently it has become popular for asset management companies that manage a range of pension products, provident products and other funds to launch their own unit trust funds. By June 2005, there were 26 management companies, managing 567 different funds and representing the interests of around two million investors. Table 5 lists the number of funds and percentage of market assets per management company.

Table 5 Management companies

\begin{tabular}{|l|c|c|}
\hline Management company (total = 26) & $\begin{array}{c}\text { Number of } \\
\text { funds (567) }\end{array}$ & $\begin{array}{c}\text { Market value of } \\
\text { assets (\%) }\end{array}$ \\
\hline ABSA Fund Managers Limited & 22 & 11.65 \\
\hline Allan Gray Unit trusts Management Limited & 8 & 6.31 \\
\hline Community Growth Management Company Limited & 3 & 0.71 \\
\hline Coris Capital Collective Investment Managers Limited & 7 & 0.64 \\
\hline Coronation Management Company Limited & 23 & 3.19 \\
\hline Foord Unit Trusts Limited & 2 & 0.10 \\
\hline Innofin Management Company Limited & 2 & 0.36 \\
\hline Investec Fund Managers SA Limited & 25 & 8.40 \\
\hline Investment Solutions Unit Trusts Limited & 14 & 3.27 \\
\hline m Cubed Unit trusts Management Company Limited & 53 & 8.34 \\
\hline Marriott Unit trusts Management Company Limited & 12 & 1.67 \\
\hline Metropolitan Collective Investments Limited & 55 & 1.60 \\
\hline Momentum Collective Investment Limited & 15 & 0.74 \\
\hline Ned group Collective Investments Limited & 37 & 4.04 \\
\hline Oasis Crescent Management Company Limited & 10 & 1.20 \\
\hline Old Mutual Unit Trusts Managers Limited & 54 & 7.51 \\
\hline Prescient Management Company Limited & 9 & 0.93 \\
\hline Prudential Portfolio Managers Unit Trusts Limited & 11 & 3.13 \\
\hline PSG Collective Investments Limited & 12 & 0.51 \\
\hline Rezco Collective Investments Limited & 1 & 0.01 \\
\hline RMB Unit Trusts Limited & 35 & 3.16 \\
\hline Sage Unit Trusts Limited & 17 & 2.10 \\
\hline Sanlam Collective Investments Limited & 66 & 9.03 \\
\hline Satrix Collective Investment Scheme Limed & 3 & 1.68 \\
\hline Stanlib Collective Investments Limited & 57 & 17.18 \\
\hline Strategic Investment Service (SIS) Management Company & 14 & 2.54 \\
\hline Limited & & \\
\hline Soure: Lambrechts (June 2005) & 25 \\
\hline
\end{tabular}

Source: Lambrechts (June 2005) 
Stanlib Collective Investments and ABSA Fund Managers are the largest companies, representing $17.18 \%$ and $11.65 \%$ of the market share. It is interesting to note that ABSA Fund Managers control the second largest percentage of assets (11.66\%), but manage only 22 different funds. In contrast to this, Metropolitan Collective Investment, a relatively small investment company (with less than $2 \%$ of total assets), manages a total of 55 different funds.

Some asset management companies use a 'team approach', where no single individual is responsible for managing a fund. Others prefer the philosophy of definite responsibility and give one portfolio manager overall authority to make investment decisions. By October 2005 , single portfolio managers managed $82 \%$, or 484 of the 588 different funds available at that time, as indicated in Table 6.

Table 6 Single portfolio manager versus a team approach

\begin{tabular}{|l|c|c|}
\hline Type of management & October $\mathbf{2 0 0 5}$ & Percentage \\
\hline Single portfolio manager & 484 funds & $82 \%$ \\
\hline Management team & 104 funds & $18 \%$ \\
\hline Total & $\mathbf{5 8 8}$ funds & $\mathbf{1 0 0 \%}$ \\
\hline
\end{tabular}

Source: Profile (2006).

In the USA, in 1945, investment committees managed almost all the major funds. By the end of 2004, a total of 3387 (81\%) of the 4194 equity funds were managed by single portfolio managers.

The worldwide trend of moving away from a 'team approach' to a single portfolio manager represents a more entrepreneurial, freeform, aggressive and less risk-averse approach to investment.

\subsection{Change in unit trusts' shareholding of JSE equities}

The South African unit trust industry remains comparatively small by international standards. South African unit trusts only hold $4.81 \%$ of corporate equity. This percentage has, however, increased from a low base of $1.83 \%$ in 1992 (as indicated in Table 7). In the USA, mutual funds own nearly $25 \%$ of US equity, which also means that these funds have a considerable influence on and responsibility towards corporate governance. With less than $5 \%$ shareholding in equities, South African unit trusts do not really have this influence or responsibility. 
The unit trust industry in South Africa from 1965 to June 2005: are investors better off?

Table 7 Unit trust shareholding in JSE equities

\begin{tabular}{|l|c|c|c|}
\hline Year & $\begin{array}{c}\text { JSE market capitalisation } \\
\text { (R bn) }\end{array}$ & $\begin{array}{c}\text { Unit trust assets as a } \\
\text { percentage of market value }\end{array}$ & $\begin{array}{c}\text { Unit trust equities as } \\
\text { a percentage of } \\
\text { market value }\end{array}$ \\
\hline 1992 & 531489 & $2.65 \%$ & $1.83 \%$ \\
\hline 1993 & 737632 & $2.64 \%$ & $1.82 \%$ \\
\hline 1994 & 919803 & $2.86 \%$ & $2.15 \%$ \\
\hline 1995 & 1022656 & $3.29 \%$ & $2.45 \%$ \\
\hline 1996 & 1129948 & $3.88 \%$ & $2.93 \%$ \\
\hline 1997 & 1129362 & $5.46 \%$ & $3.19 \%$ \\
\hline 1998 & 1001556 & $7.12 \%$ & $3.39 \%$ \\
\hline 1999 & 1616207 & $6.94 \%$ & $3.04 \%$ \\
\hline 2000 & 1551488 & $8.27 \%$ & $3.87 \%$ \\
\hline 2001 & 1379517 & $12.66 \%$ & $4.20 \%$ \\
\hline 2002 & 1584151 & $11.35 \%$ & $3.98 \%$ \\
\hline 2003 & 1787194 & $12.89 \%$ & $4.57 \%$ \\
\hline 2004 & 2566352 & $11.92 \%$ & $4.57 \%$ \\
\hline Sep 2005 & 3286468 & $11.89 \%$ & $4.81 \%$ \\
\hline
\end{tabular}

Source: ACl (2006)

Ownership of unit trusts has changed over time. From the management of only retail unit trusts in 1965, unit trusts now manage both retail and institutional funds. A retail fund can be defined as a fund in which the individual investor/unit holder can invest directly or indirectly and where the investment is held in the name of the individual investor (ACI 2005). This includes funds which can be accessed directly through a management company. An institutional fund, on the other hand, is a fund in which the individual investor/unit holder cannot invest. The units are not held in the name of individual investors, but are held in the name of a structure such as a pension or a provident fund; and the value of units is used solely for determining the liability of the legal persona to the investor. Institutional funds would include investments by pension funds, provident funds, retirement funds, companies and group money, endowment policies and structured funds.

By June 2005, a total of 114 of the 567 unit trusts were institutional unit trusts, representing $24.47 \%$ of the total assets held. In the USA, the percentage is much higher institutional funds there represent nearly $40 \%$ of the industry's assets. This could indicate that in the USA investors in general regard a unit trust more as a long-term investment than the average South African investor does, and US investors use the expected high return from the market as a pension-generating asset.

\subsection{Changes in the investment strategies of portfolio managers}

With the development of more aggressive funds and the shift away from a 'team approach' to portfolio managers, it seems that the emphasis has also shifted away from long-term investment toward short-term performance. In Table 8, the turnover rate of equity funds is given for selected years. For the purposes of this study, Bogle's (2005:18) definition of the turnover rate is used, namely turnover rate is the sales per annum (four quarterly sales added), expressed as a percentage of the total assets at the end of the year. Quarterly sales values for South African unit trusts were obtained from ACI (2006). 
Table 8 Portfolio turnover rates for equity funds (based on units sold)

\begin{tabular}{|c|c|c|}
\hline Year & Turnover rate & Average holding period \\
\hline 1998 & 61.4 & 20 months \\
\hline 1999 & 48.4 & 25 months \\
\hline 2000 & 61.0 & 20 months \\
\hline 2001 & 38.7 & 22 months \\
\hline 2002 & 32.8 & 37 months \\
\hline 2003 & 28.3 & 42 months \\
\hline 2004 & 33.4 & 36 months \\
\hline
\end{tabular}

Turnover rate is defined as sales per annum, expressed as a percentage of total assets at the end of the year.

From Table 8, it is clear that, over the last eight years, South African fund managers have turned their equity portfolios over at rates of between $28.3 \%$ and $61.4 \%$. This implies that the average shares were held for 20 to 42 months. If a long-term strategy is classified as holding investments for longer than five years, then long-term investment strategies definitely no longer seem to govern the unit trusts industry. It seems that, in many instances, short-term speculation has replaced conservative long-term investing strategies in South Africa.

Evidence of this type of speculation is even higher in the USA than in South Africa. In 1945 , in the USA, the annual portfolio turnover (on equity funds) averaged a steady 17\%, suggesting that the average fund held its stock for about six years. Fund managers now turn their portfolios over at an average rate of $110 \%$ annually - this implies that average stock is now held by an average fund for only 11 months. The increase in turnover rates worldwide must have a damaging effect on investors' returns. As trading costs increase, such turnover rates can benefit only the management companies, not the investors.

It should be admitted, however, that the turnover rates alone do not tell the full story of the role of unit trusts/mutual funds in the financial markets. The total turnover rate for the whole industry in 2004 was $87 \%$, which includes fixed interest funds and money market funds. The rand value involved is enormous. For example, at a $90 \%$ turnover rate, today's managers would sell R311 billion of securities in a single year and then reinvest those R311 billion in other securities, R622 billion in total. It is difficult to imagine that, if transaction costs are taken into account, investors can benefit from such transactions. However, Table 8 shows only equity funds, as money market funds may be involved in buying and selling short-term securities, with only three months to maturity, which could distort the picture.

\subsection{Changes in the time period that investors invest in unit trusts}

With the relatively high entry costs of unit trusts, unit trusts are generally not considered good investments over three- to six-month periods. Short-term performance does not always correlate well with long-term performance; in other words, unit trusts are generally regarded as good long-term investments. Long-term performance is then more important than short-term performance. It seems, however, that many investors may be responding to short-term fluctuations in performance, perhaps due to marketing strategies, which focus on these fluctuations.

In Table 9 the annual turnover rates and average investment periods of investors in equity funds are given for selected years. The turnover rate is defined here (in line with Bogle 2005:19) as repurchase values per year (the sum of quarterly values) expressed as a 
percentage of the total assets. The quarterly repurchase values were obtained from ACI (2006).

Table 9 Annual turnover rates of units by investors (based on units repurchased)

\begin{tabular}{|c|c|c|}
\hline Year & Turnover rate & Average holding period \\
\hline 1998 & 48.9 & 25 months \\
\hline 1999 & 41.9 & 29 months \\
\hline 2000 & 48.6 & 25 months \\
\hline 2001 & 40.2 & 30 months \\
\hline 2002 & 40.6 & 30 months \\
\hline 2003 & 27.7 & 43 months \\
\hline 2004 & 34.0 & 35 months \\
\hline
\end{tabular}

From Table 9, it is clear that the behaviour of investors in unit trusts has changed. In 1965, investors bought units in broadly diversified funds and held on to them as long-term investments. In South Africa, the turnover rate for investors in unit trusts in 2004 was 34\%, meaning that the average investor kept his/her investment for a mere 35 months, or less than three years. Between 1998 and 2004, the average turnover of units by investors was about $40 \%$, which corresponds with a holding period of 30 months, or two and a half years.

This trend of an increase in portfolio turnover is also evident in the USA. In the 1950s, fund redemption averaged $6 \%$ of assets annually, which suggests that the average investor held his/her shares for about 16 years. The average holding period is now between three and four years. Again, South African investors act in line with international trends. Investors are either convinced by marketing strategies suggesting short-term trading of units, or are uninformed about the hidden costs involved.

\subsection{Increases in the creation of new funds and the closing down/merging of existing funds}

The creation of new funds began to escalate from 2000 onwards. More funds have been created in the six-year period from January 2000 to December 2005 than in the entire preceding period since 1965. By December 2000, there were only 334 different funds, while 391 new funds were created from January 2000 to December 2005.

With the creation of more risky funds, a number of funds went out of business (or rather, ceased to exist as separate funds), usually merging into other, better performing funds in the same family. The failure of funds also increased over the 40 -year period. During the 25-year period from 1965 to 1990, only one fund closed down, but over the next decade, 57 had ceased to exist as separate funds. Over the next six-year period until June 2005, 54 funds had closed down, as indicated in Table 10.

Table 10 Formation and liquidation of funds

\begin{tabular}{|l|c|c|}
\hline Year & Number of new funds & Number of dying funds \\
\hline 1979 & 12 & 0 \\
\hline 1989 & 19 & 1 \\
\hline 1999 & 286 & 57 \\
\hline 2005 & 391 & 54 \\
\hline
\end{tabular}

Sources: ACl (2006) and Profile (2006). (Figures are summed per decade)

Once again, the situation in South Africa is in line with international trends. In the USA, the increased creation and failure of funds is also evident. Over the period from 2000 to 2004, a total of 980 equity funds were created, while 1045 disappeared. This worldwide 
trend of an increase in the number of and failure of funds implies increased losses and costs to investors.

\subsection{Changes in the cost structure of unit trusts}

Unit trusts fees and charges in South Africa were deregulated in June 1998. Prior to deregulation, unit trusts were not legally allowed to charge more than $5 \%$ for initial charges and $1 \%$ of assets as an annual management fee. After deregulation, the ceiling on annual fees was removed, meaning that funds launched after deregulation do not have the same restrictions imposed on them. Market forces thus determine fees; and the actual cost incurred can differ from fund to fund.

Each unit trust fund has a different fee and charge structure, but these costs can be broadly classified into two categories, according to ACI (2005):

initial fees as once-off entry costs; and

management (service) fees as annual costs.

Initial fees are levied when an investor purchases units, be it an initial lump sum, an additional deposit or a debit order. Generally speaking, the higher the investment amount, the lower the percentage fee as an initial charge. Initial fees are charged by the management company. A portion of the initial fee is used to pay broker commission; and the remainder covers marketing and administration costs. These fees are deducted from the amount invested and can range between $1 \%$ and $5 \%$. However, since deregulation has come into effect, there are no maximum restrictions in terms of initial charges. Some management companies do not charge initial fees at all, which is in line with the international 'no-load' trend. In South Africa, VAT on initial charges is levied at a rate of $14 \%$.

The management company that administers the units and manages the investments also levies annual service fees. Prior to deregulation, these charges had a ceiling of $1 \%$. VAT of $14 \%$ is payable on this service fee. These fees are calculated on a daily basis, and are automatically deducted from income distributions.

Some management companies pay broker fees out of the annual management fee. These are so-called trailer fees, which are paid to brokers to provide on-going investment advice to their clients. Fees are levied if an investor switches from one fund to another. Some companies charge a fixed fee for each switch, but most do not charge for switching between funds within the same management company. Some management companies do not levy initial fees or charge a reduced initial fee but levy an exit fee. This is paid if an investment is sold within a certain length of time, for instance, within the first year, and it is based on the original capital, as well as on the growth of the fund.

Performance-based fees have recently been introduced to the market. Instead of charging a fixed annual fee of, say, $1 \%$, annual fees are linked to the performance of the fund. A maximum performance fee is charged if the fund exceeds a given relevant benchmark, for example, the JSE All Share Index, by a certain percentage. Should a fund under-perform its benchmark, the annual fees may be waived entirely.

In the USA, the average expenses ratio (total management fees and operating expenses as a percentage of fund assets) for the largest 25 funds in 1945 was $0.76 \%$. Six decades later, the average expenses ratio of the largest 25 funds is $1.56 \%$, representing a $105 \%$ increase. South African data is unfortunately not currently available to calculate an expense ratio, but it can be assumed that, with deregulation, costs in South Africa have also increased. The 
high cost factor could have reduced the returns of investors as discussed in the following paragraph.

\section{Are South African investors better off with these changes?}

Clearly, the unit trust industry of 2005 is very different from that of 1965 . It is larger, more diverse, with more speculative funds focused on shorter investment periods. Investors hold units in funds for shorter periods; and the industry seems to focus on accumulating assets and marketing its products to investors. With all of these changes, it is justifiable to ask whether investors are better off or not. Table 11 shows that over the past 17 years (from 1988 to 2005) investors could have obtained an average return of nearly $18 \%$ by investing in the JSE All Share index fund.

Table 11 The average performance of unit trusts versus the JSE All Share Index

\begin{tabular}{|c|c|c|c|c|}
\hline Year & All share index & $\begin{array}{c}\text { Buy/sell } \\
\text { (Costs included) }\end{array}$ & $\begin{array}{c}\text { Sell/sell } \\
\text { (Costs excluded) }\end{array}$ & Initial cost \\
\hline 1988 & 14.82 & 16.98 & 25.09 & 8.1 \\
\hline 1989 & 55.5 & 35.7 & 45.66 & 10 \\
\hline 1990 & 5.15 & -0.57 & 6.84 & 7.4 \\
\hline 1991 & 31.02 & 24.71 & 33.65 & 8.9 \\
\hline 1992 & -2.04 & -1.05 & 5.85 & 6.9 \\
\hline 1993 & 21.25 & 7.79 & 15.13 & 7.3 \\
\hline 1994 & 22.65 & 21.28 & 30.51 & 9.2 \\
\hline 1995 & 8.79 & 6.76 & 13.15 & 6.4 \\
\hline 1996 & 9.32 & 2.85 & 10.11 & 7.3 \\
\hline 1997 & -4.5 & -0.38 & 5.88 & 6.3 \\
\hline 1998 & -10.05 & -12.01 & -6.36 & 5.7 \\
\hline 1999 & 61.39 & 35.29 & 43.57 & 8.3 \\
\hline 2000 & -0.11 & -8.1 & -3.13 & 5 \\
\hline 2001 & 29.05 & 11.46 & 17.85 & 6.4 \\
\hline 2002 & -8.09 & -6.01 & -0.88 & 5.1 \\
\hline 2003 & 16.09 & 14.81 & 20.95 & 6.1 \\
\hline 2004 & 25.46 & 31.29 & 37.82 & 6.5 \\
\hline 2005 & 47.8 & 41.92 & 48.61 & 6.7 \\
\hline Average return & $\mathbf{1 7 . 9 7}$ & $\mathbf{1 2 . 3 7}$ & $\mathbf{1 9 . 4 6}$ & $\mathbf{7 . 1}$ \\
\hline
\end{tabular}

Sources: Lambrechts (Unit trust surveys 1988-2005).

From Table 11, it seems that general equity fund managers were successful in outperforming the market. By timing the market and selecting better performing shares, they earned an average return of $19.5 \%$ for their investors, $1.5 \%$ more than the market average. If, however, costs are taken into consideration, the picture changes completely. The average return for shareholders (buy to sell) over this period was only $12.4 \%$.

The evidence is compelling that equity fund returns lag the stock market by a substantial amount, largely due to the costs involved. Evidence of this trend can also be found in the USA, where, for the 20 years from 1983 to 2003, the average stock market return was 13\%, whereas the average equity fund return was only 10.3\% (Bogle 2005:23). Once again comparisons between the two industries could be difficult because different periods and 
different inflation rates apply. However, the trend is clearly that investors have received modest returns during periods in which the stock markets were providing returns well above the long-term average.

\section{A comparison between the South African and US industries}

To draw comparisons between the South African unit trust industry and that of the USA could be problematic. Different periods are involved and different inflation rates were present over these periods. The South Africa unit trust industry is almost insignificant ( $0.3 \%$ of world assets) compared to the US market, which represents $50 \%$ of the worldwide mutual fund assets. The US industry is also much older, at 60 years, versus the 40 years of the South African industry. However, it seems from Table 12 that what has happened in the US market also occurred in South Africa, only on a smaller scale.

Table 12 Comparison between the South African unit industry and the US mutual fund industry

\begin{tabular}{|c|c|c|}
\hline & $\begin{array}{l}\text { SA unit trusts industry } \\
(1965-2005)\end{array}$ & $\begin{array}{l}\text { USA mutual fund industry } \\
(1945-2004)\end{array}$ \\
\hline $\begin{array}{l}\text { Compounded annual growth rate of } \\
\text { economy }\end{array}$ & $14 \%$ & $7 \%$ \\
\hline Compounded growth rate of industry & $39 \%$ & $16 \%$ \\
\hline $\begin{array}{l}\text { Fund composition: } \\
\text { Equity/ hybrid funds } \\
\text { Fixed interest funds } \\
\text { Money market funds }\end{array}$ & $\begin{array}{c}567 \text { funds } \\
49 \% \\
18 \% \\
33 \% \\
\end{array}$ & $\begin{array}{c}8170 \text { funds } \\
57 \% \\
17 \% \\
26 \% \\
\end{array}$ \\
\hline $\begin{array}{l}\text { Equity funds (in numbers) } \\
\text { General equity } \\
\text { Specialised } \\
\text { Balance/Managed } \\
\text { International }\end{array}$ & $\begin{array}{l}437 \text { funds } \\
73(32 \%) \\
79(23 \%) \\
199(34 \%) \\
86(11 \%) \\
\end{array}$ & $\begin{array}{l}4204 \text { funds } \\
579(14 \%) \\
455(11 \%) \\
2486(59 \%) \\
686(16 \%) \\
\end{array}$ \\
\hline Institutional funds \% of total industry & $24,47 \%$ & $40 \%$ \\
\hline $\begin{array}{l}\text { Management by single portfolio } \\
\text { manager }\end{array}$ & $\begin{array}{l}82 \% \text { (484 funds out } \\
\text { of (588) }\end{array}$ & $\begin{array}{c}81 \% \text { (3 } 387 \text { funds out of } \\
\text { R4 194) }\end{array}$ \\
\hline Portfolio turnover (investment period) & $33.4 \%(36$ months $)$ & $112 \%$ (11 months) \\
\hline Investors holding period & $34.0 \%(35$ months) & $24.8 \%$ (4 years) \\
\hline $\begin{array}{l}\text { Unit trust ownership of stock market } \\
\text { shares) }\end{array}$ & $4.81 \%$ & $24.9 \%$ \\
\hline $\begin{array}{l}\text { Creation of new funds over the last } 4-5 \\
\text { years }\end{array}$ & 391 funds & 980 funds \\
\hline Liquidation/merging of funds & 54 funds & 1045 funds \\
\hline Average expense ratio & Not available & $1.56 \%$ \\
\hline Stock market return & $\begin{array}{c}\text { 18\%(All share index) } \\
(1988-2005)\end{array}$ & $13 \%$ (S\&P500) (1983-2003) \\
\hline Average equity fund return & $12.4 \%$ & $10.3 \%$ \\
\hline
\end{tabular}

The following similarities can be noted: 
Both industries experienced growth rates of more than twice that of their economies. This definitely highlights the importance of unit trusts as an investment vehicle.

Equity funds are important as investments products in both industries, representing about $50 \%$ of assets. Equity investments are still the preferred choice for portfolio return enhancement and risk management.

Broad diversified portfolio funds (general equity) decreased over time. Today, only $32 \%$ (South Africa) and 14\% (USA) of equity assets are invested in general equity funds. This proves that the market regards management skills and actively managed portfolios as important.

Institutional funds are important; in South Africa they represent nearly $25 \%$ of the market and in the USA $40 \%$.

Single portfolio managers managed the majority (82\%) of funds in South Africa. In the USA, this figure is $81 \%$; again emphasizes a global shift to a more aggressive and less risk-averse approach to investments.

Portfolio turnover has increased in both industries. The average period of investment for portfolio managers in South Africa was three years, while this figure was less than a year in the USA market. The South African industry is following the bigger market and is replacing long-term investment strategies with short-term speculation.

The average holding period for investors in unit trusts was around three years for South Africa and about four years for the USA market, again emphasizing the investor sensitivity to marketing strategies.

Shareholding of stock market equities increases in both markets. In South Africa, shareholding represents $4.8 \%$, and in the USA this figure is nearly $25 \%$.

There is evidence of an increase in the creation of new funds in both industries, as well as of an increase in the liquidation or merging of funds, emphasizing again the increased costs and risks for unit trust investors.

Managing and marketing costs have increased in both industries.

The average equity fund underperformed the stock market in both countries over the periods studied, perhaps due to the increased charges and fees levied.

\section{Suggestions to offer investors more value}

Over time the unit trust industry has experienced an increase in size and the inclusion of different types of products and services offered to investors. All these changes were not always in the best interests of investors. The following steps are needed to add further value and enhance investors' returns:

\subsection{Reducing operating costs}

The only way to enhance investors' returns in unit trusts investments is to reduce the portfolio turnover costs by, for example, reducing the turnover rate. Reducing management fees and sales commission by introducing a performance-based fee may also be possible. Cutting operating and marketing costs by offering a smaller amount of products to the investor could be another way of reducing costs. 


\subsection{Changing investment strategies}

The industry could again focus on broadly diversified funds with sound objectives and long-term investment strategies. Marketing strategies could be changed in order to prove to investors that their investments' long-term performance could improve if buy-and-hold strategies are followed, rather than trading unit trusts over the short-term.

\subsection{Educating South African investors}

South African investors need to be educated about asset allocation, fund selection risk, potential returns and especially the costs involved. Investors may need to be educated about the fact that unit trusts need to be long-term investments and not to be misled by the returns of individual quarters.

\section{Areas for further research}

In South Africa it seems that general equity funds have outperformed the All Share Index over the past 17 years. This raises questions about whether the same is true for other specialized equity funds, fixed interest funds and money market funds. Can this performance be associated with superior stock-picking ability or superior timing ability?

The underperformance of funds when costs are taken into account offers areas for further research. How can these costs be split between the expense ratio and the transaction cost of the fund? Is there a relationship between the size of a fund and the costs involved? Is there a relationship between the size, costs and performance of funds? Funds with higher turnover rates normally incur higher transaction costs and charge higher expenses, which could also be investigated for the South African market.

It will be of great interest whether managers of actively managed funds are able to add value net of taxes. Is there a difference between the performance of funds that are managed by a single portfolio manager and those that are managed by a 'team approach'? Previous unit trust studies in South Africa were constrained by the small number of funds that were available and the short time for which such funds had been in existence. This situation has changed and new opportunities for research have now emerged.

This study may contribute to a better understanding of trends in the South African unit trust industry. This may enable the industry to serve its customers better in future and investors to obtain better returns on long-term investments.

\section{Bibliography}

ACI (Association of Collective Investments). 2005. Fact sheet: Everything you want to know about unit trust fees and charges. http://www.aci.co.za/euntk.html Accessed 1 February 2006.

ACI (Association of Collective Investments). 2006. Local fund quarterly statistics. http://www.aci.co.za Accessed 2 February 2006.

Akinjolire, A. \& Smit, E.V.D.M. 2003. South African unit trust performance and strategy in a changing climate (1998-2002). Investment Analysts Journal, 58:41-50. 
Barber, B., Odean, T. \& Zheng, L. 2005. Out of sight, out of mind: the effects of expenses on mutual fund flows. The Journal of Business, 78(6):2095-2119.

Bogle, J.C. 2005. The mutual fund industry 60 years later: for better or worse? Financial Analysts Journal, 61(1):15-24.

Collinet, L. \& Firer, C. 2003. Characterising persistence of performance amongst South African general equity unit trusts. Omega, 31(6):523-533.

Deaves, R. 2004. The comparative performance of load and no-load mutual funds in Canada. Canadian Journal of Administrative Sciences, 21(4):326-333.

Ellingham, I. 1995. Authorised property unit trusts and the Canadian experience. Journal of Property Finance, 6(1):28-35.

Fletcher, J., Forbes, D. \& Marshall, A. 2002. An investigation of the impact of derivative use on the risk and performance of UK unit trusts. Financial Services Review, 11(2):173-187.

Fletcher, J. \& Marshall, A. 2005. An empirical examination of U.K. unit trust performance. Journal of Financial Services Research, 27(2):183-206.

Gaber, M., Gregoriou, G.N. \& Kelting, W. 2004. Funds of hedge funds: ethics of this black box strategy. Pensions: An International Journal, 9(4):328-335.

Gronewoller, P.L., McLeod, J. \& Rose, L.C. 2001. Style analysis: is it useful in analyzing New Zealand managed trusts? Pacific Accounting Review, 13(1):1-17.

Hayes, S.K. 2005. Socially responsible mutual funds: issues to consider when investing with your conscience. Journal of Financial Service Professionals, 59(5):59-63.

ICI (Investment Company Institute). 2005. Worldwide Mutual Fund Asset and Flows, Second Quarter. http://www.ici.org/issues/glo/ww 06 05.html Accessed 1 February 2006.

Kee, K.S. 1999. A survey of unit trusts in Singapore. Singapore Management Review, 21(1):49-78.

Kjetsaa, R. 2004. Actively managed equity mutual fund performance relative to benchmarks. American Business Review, 22(1):102-115.

Krell, E. 2005. The changing face of retirement. Baylor Business Review, 23(1):26-31.

Lambrechts, H. 1988-2005. Unit trusts survey, Quarterly reports. Pretoria: University of Pretoria.

Lambrechts, H. (ed.). 1995. Unit trusts handbook. Johannesburg: Profile Media. September.

Lin, M.C. 2006. An examination of the determinants of mutual fund performance over different investment horizons. International Journal of Management, 23(1):147-156.

Noulas, A.G., Papanastasiou, J.A. \& Lazaridis, J. 2005. Performance of mutual funds. Managerial Finance, 31(2):101-112.

Oldert, N. (ed.). 2005. Profile's unit trusts \& collective investments. Johannesburg: Profile Media.

Oldham, G. \& Kroeger, J.A. 2005. Performance, persistence and benchmarks of selected South African unit trusts for the period 1998-2002. South African Journal of Business Management, 36(4):81-90. 
Pinnuck, M. 2003. An examination of the performance of the trades and stock holdings of fund managers: further evidence. Journal of Financial and Quantitative Analysis, 38(4):811-828.

Profile. 2006. Funds data. 2005 http://www.profile.co.za/ Accessed 2 February 2006.

Ramasamy, B. \& Yeung, M.C.H. 2003. Evaluating mutual funds in an emerging market: factors that matter to financial advisers. The International Journal of Bank Marketing, 21(2):122-136.

Rusconi, R. 2005. Costs of saving for retirement in South Africa. Pensions: An International Journal, 11(1):16-29.

South African Reserve Bank. 2005. Gross domestic product at market prices. http://www.resbank.co.za/economics/netqb2/NetQbMain.asp. Accessed 1 February 2006.

Tessitore, A. \& Usmen, N. 2005. Decomposing performance of funds-of-funds. Journal of American Academy of Business, 6(1):150-154.

Wessels, D.R. \& Krige, J.D. 2005. The persistence of active fund management performance. South African Journal of Business Management, 36(2):71-82. 